\title{
Regulasi Emosi Perawat Ruang Rawat Inap Klinik Utama Rawat Inap Usada Buana Surabaya
}

\author{
Nursing Emotional Regulation of \\ Klinik Utama Rawat Inap Usada Buana Surabaya
}

\author{
${ }^{1}$ Ade Ayu Mitra Ramadita Daluas, ${ }^{2}$ Suryanto, ${ }^{3}$ Sendy Ayu Mitra Uktutias \\ ${ }^{1}$ Program Studi Magister Pengembangan Sumber Daya Manusia Universitas Airlangga, \\ ${ }^{2}$ Fakultas Psikologi Universitas Airlangga, ${ }^{3}$ Program Studi Doktor Pengembangan \\ Sumber Daya Manusia Universitas Airlangga. \\ e-mail: 1ade.ramadita-2017@pasca.unair.ac.id, 록yanto@psikologi.unair.ac.id, \\ ${ }^{3}$ sendy.ayu.mitra-2018@pasca.unair.ac.id
}

\begin{abstract}
ABSTRAK
Regulasi emosi merupakan kemampuan yang dimiliki seseorang untuk mengelola emosi yang tepat untuk mencapai keseimbangan emosional. Tujuan penelitian ini adalah untuk mendeskripsikan regulasi emosi perawat ruang rawat inap dan mengetahui model regulasi emosi yang tepat untuk perawat ruang rawat inap. Penelitian ini menggunakan pendekatan kualitatif dengan desain fenomenologi. Teknik pengumpulan data menggunakan wawancara dan analisis. Sampel dalam penelitian ini adalah perawat ruang rawat inap di Klinik Utama Rawat Inap Usada Buana. Hasil penelitian ini menunjukkan bahwa perawat ruang rawat inap mengalami regulasi emosi yaitu perasaan kurang dihargai oleh pasien ketika perawat ruang rawat inap mengingatkan saat mengganti cairan infus, minum obat dan mengingatkan waktu. Model regulasi emosi yang tepat untuk perawat ruang rawat inap dengan model regulasi emosi proses koping. Proses koping diawali dengan problem-focused coping, dilanjutkan dengan appraisal-focused coping dan diakhiri dengan emotion-focused coping. Pentingnya regulasi emosi perawat ruang rawat inap sehingga melalui pemberian dorongan setiap perawat dengan simulasi dan sharing dalam menghadapi pasien yang sulit, melatih keterampilan komunikasi antar perawat dalam seminggu sekali.
\end{abstract}

Kata Kunci : Model Regulasi Emosi; Perawat; Ruang Rawat Inap.

\section{ABSTRACT}

Emotional regulation is the ability a person has to manage emotions right to achieve emotional balance. The purpose of this study was to describe the emotional regulation of inpatient nurses and to know the appropriate emotion regulation model for inpatient nurses. This study uses a qualitative approach with phenomenological design. Data collection techniques using interviews and analysis. The sample in this study was an inpatient nurse at Klinik Utama Rawat Inap Usada Buana. The results of this study indicate that inpatient nurses experience emotional regulation that is a feeling of being undervalued by patients when the inpatient nurse reminds when replacing intravenous fluids, taking medication and reminding of wasting time. The emotion regulation model is appropriate for inpatient nurses with emotion regulation coping models. The coping process begins with problem-focused coping, followed by appraisal-focused coping and ends with emotion-focused coping. The importance of emotional regulation of inpatient nurses so that through encouraging each nurse with simulation and sharing in dealing with difficult patients, practice communication skills between nurses in a week.

Keyword : Emotion Regulation Model; Inpatient Room; Nurse. 


\section{PENDAHULUAN}

Pelayanan kesehatan merupakan faktor penentu baik atau buruknya mutu dan citra sebuah rumah sakit, oleh karena itu kualitas pelayanan perlu dijaga dan ditingkatkan. Perawat adalah komponen utama dalam sistem pelayanan kesehatan, dan perawat merupakan kelompok yang paling besar dalam sistem pelayanan di klinik rawat inap. Baik atau buruknya kinerja perawat menjadi salah satu faktor utama penentu kualitas pelayanan keperawatan di klinik rawat inap dan sangat penting untuk meningkatkan kualitas sumber daya manusia di bidang keperawatan (Ariani \& Kristiana, 2017).

Perawat adalah profesi atau tenaga kesehatan yang jumlah dan kebutuhannya paling banyak di antara tenaga kesehatan lainnya. Undang-Undang Nomor 38 tahun 2014 menjelaskan Perawat adalah seseorang yang telah lulus pendidikan tinggi keperawatan, baik di dalam maupun di luar negeri yang diakui oleh Pemerintah sesuai dengan ketentuan Peraturan Perundang-undangan. Rasio tenaga perawat terhadap 100.000 penduduk Provinsi Jawa Timur adalah 1:103, dengan penduduk Jawa Timur 38.847.561 jiwa dan tersedianya tenaga kesehatan perawat di fasilitas pelayanan kesehatan sebanyak 1.675 tenaga kesehatan perawat (Kemenkes, 2017). Berdasarkan data tersebut perawat memiliki tuntutan kerja yang tinggi, hal tersebut disebabkan karena perawat memiliki peran dan tanggung jawab yang besar (Maharja, 2015).

Pelayanan yang diberikan oleh perawat haruslah memperhatikan nilai-nilai pelanggan yang dibutuhkan dan diinginkan pasien agar pasien yang dirawat di rumah sakit tersebut merasa puas atas pelayanan yang diberikan (Gunawan, 2017). Pekerjaan perawat yang berhubungan dengan nyawa pasien serta dihadapkan pada masalah yang muncul di lingkungan kerja yaitu penilaian negatif masyarakat terhadap profesi perawat, pasien yang sering mengeluh, pembagian jasa yang kurang merata, dan kelelahan fisik dapat memunculkan kondisi stres pada perawat (Anggraini \& Prasetyo, 2015).

Penelitian yang dilakukan The National Institute Occupational Safety and Health (NIOSH) menunjukkan bahwa pekerjaan yang berhubungan dengan rumah sakit atau kesehatan memiliki kecenderungan tinggi untuk terkena depresi (Madol, 2016). Scheier dalam Soejitno (2002) yang dikutip Sarafino (2002) mengungkapkan bahwa perawat yang mengalami tingkat depresi paling tinggi adalah perawat bagian rawat inap dan unit gawat darurat. Tingkat depresi yang tinggi tersebut timbul karena keadaan pekerjaan yang mengharuskan perawat melakukan tindakan terhadap pasien yang harus segera dibuat dan dilakukan secara tepat dan cepat karena tingkat kesibukan yang tinggi dan keadaan gawat 
Ade Ayu Mitra Ramadita Daluas, Suryanto, Sendy Ayu Mitra Uktutias : Nursing Emotional Regulation ....

darurat menyangkut kehidupan dan kematian pasien dan diri mereka sendiri (Madol, 2016).

Madol (2016) Pelayanan keperawatan sangat memerlukan sosok perawat yang memiliki kecerdasan emosi yang tinggi untuk memenuhi kebutuhan pasien yang mencakup kebutuhan biologis, psikologis, sosiologis dan spiritual. Ariani \& Kristiana (2017), mengatakan bahwa perawat merupakan salah satu pekerja yang berkaitan erat di bidang pelayanan yang memiliki kemampuan dalam mengekspresikan emosi-emosi yang diinginkan secara organisasional selama melakukan interaksi dengan pasien di rumah sakit dan perawat dituntut untuk dapat mengelola emosi.

Hasil observasi peneliti yang dilakukan pada bulan November 2018, di Klinik Utama Rawat Inap Usada Buana Kota Surabaya menunjukkan masih banyak perawat dalam memberikan asuhan keperawatan kepada pasien rawat inap, sikapnya kurang sabar, kurang ramah, kurang perhatian, kurang semangat, serta kurang bersedia menolong. Penelitian yang dilakukan oleh Yuni Widayanti (2007) dengan mengambil 55 responden menunjukkan 36,4\% dengan kecerdasan emosi kurang, 30,9\% dengan kecerdasan emosi cukup, dan 32,7\% dengan kecerdasan emosi baik, artinya secara umum tingkat kecerdasan emosinya kurang baik. Kecerdasan emosi yang cenderung kurang dampaknya dalam memberikan asuhan keperawatan kurang optimal.

Menurut Silaen \& Dewi (2015), Salah satu bagian dari kecerdasan emosi yang dapat dilatih adalah regulasi emosi. Menurut Mayangsari \& Ranakusuma (2014), Regulasi emosi adalah kemampuan yang dimiliki seseorang untuk menilai, mengatasi, mengelola dan mengungkapkan emosi yang tepat untuk mencapai keseimbangan emosional. Kemampuan yang tinggi dalam mengelola emosi meningkatkan kemampuan individu untuk menghadapi ketegangan dalam kehidupannya.

Melihat fenomena di atas, sangat penting bagi seorang perawat untuk memiliki kecerdasan emosi, di samping ketrampilan dibidang perawatan kesehatan. Orang dengan kecerdasan emosi yang berkembang baik berarti kemungkinan besar bahagia dan berhasil dalam kehidupan, menguasai kebiasaan pikiran yang mendorong produktifitas mereka dan dapat menata emosi dengan baik (Goleman, 2007).

\section{METODE}

Penelitian ini menggunakan teknik sampling dengan random sampling. Menggunakan pendekatan kualitatif dengan desain fenomenologi. Desain fenomenologi digunakan dalam penelitian ini karena fenomena regulasi emosi perawat ruang rawat inap 
merupakan permasalahan yang dialami perawat di pelayanan fasilitas kesehatan, sehingga peneliti ingin mendeskripsikan regulasi emosi perawat ruang rawat inap dan mengetahui model regulasi emosi yang tepat untuk perawat ruang rawat inap. Teknik pengumpulan data yang digunakan dalam penelitian ini dengan teknik wawancara kepada perawat ruang rawat inap, wawancara dilakukan untuk menggali data regulasi emosi perawat ruang rawat inap.

\section{HASIL}

Hasil penelitian mengungkapkan fakta perawat yang bertugas di ruang rawat inap, yaitu perawat ruang rawat inap Klinik Utama Rawat Inap Usada Buana terdiri dari 12 orang dengan pembagian berdasarkan 3 shift yaitu pagi pada pukul 07.00-14.00 WIB, siang pada pukul 14.00-21.00 WIB dan malam pada pukul 21.00-07.00 WIB.

"Pasien kita emang banyak yang gak nurut mbak, jadi kita ikutan emosi apa ya mbak kalo dibilang itu ngerasa kurang dihargai. Em..(menatap ke atas) dan kita yang dibilang galak, kurang perhatian. Padahal kita sudah mengingatkan untuk waktunya ganti cairan infus, waktunya minum obat terus waktu seka itu mbak. Kalo seka kan mandi ya mbak. (Perawat P)”.

"Permintaan pasien kan banyak mbak, jadi kalo gak dituruti nanti kita yang diomeli dokter dan manajer mbak. jadi ya emosi mbak, kita maunya pasien juga nurut kita juga bakal ngasi perhatian lebih. (Perawat P)”.

"Iya mbak, kalo pasien memang kita gak terlalu banyak banget tapi ya Alhamdulillah pasien tiap hari yang rawat inap lumayan banyak, kadang 3 orang sekaligus masuk mbak. tapi ya gitu kita berdua belas orang yang di rawat inap tapi kan dibagi 3 shift dan ada yang libur juga ya mbak. kalo pasien lumayan banyak biasanya pasien juga rewel yang mau ini itu, diingatkan buatkan ganti cairan infus kadang ya gak mau. Kalo gitu kan kita pasti nggeremeng mbak apalagi waktu seka juga. Pasien minta perhatian lebih, kita sudah ngasi perhatian tapi kayaknya dirasa kurang terus kita yang dianggap kurang telaten.(Perawat $R$ )”.

Penelitian ini diperoleh informasi terkait kemampuan perawat di ruang rawat inap berusahan mengelola emosi dengan cara :

"Pernah saya omeli mbak, apalagi kan perawat perempuannya memang lebih banyak daripada laki-lakinya. Perawat juga manusia ya mbak, kadang kita perempuan juga ada masalah di rumah yang namanya perasaan pasti ke bawa mbak.. itu istilah sekarang baper mbak ya. Tapi alhamdulillah gak sampek marah 
Ade Ayu Mitra Ramadita Daluas, Suryanto, Sendy Ayu Mitra Uktutias : Nursing Emotional Regulation ....

yang gimana gitu mbak. Kan kalo sudah kalap mata gitu saya juga takut masuk rapot merah dari manajer mbak, manajer juga kan keliling di sini. Pokoknya kita harus lah menjaga lagi. Tiap mau marah ingetnya nanti dimarahin manajer, bukan galak sih manajer saya mbak Cuma kan ada perasaan khawatir.. takut gak di kontrak lagi.. (Perawat P)"

"Duh.. kalo pasien cowok ya banyak juga mbak. ya gitu karna perawat cowoknya Cuma 2 jadi kalo ada pasien cowok kayak pasang kateter gitu malu dan gak mau harus ngebujuk. Mulai dari situ kadang kita ya jengkel. Pokoknya tiap jengkel inget sama rapor kita. (Sambil tertawa). Terus banyak juga pasien cewek gak mau di obati perawat cowok mbak, yang cowok sama juga jengkel juga kayaknya. Kan kalo kita perawat harus gantian juga ya mbak visite kepasien. Perawat P”.

“ Saya iyakan saja mbak maunya pasien gimana, ya pernah juga saya marah mbak. Tak iyain aja mbak daripada tak ladeni nanti lapor ke dokter penganggung jawab terus saya yang dimarahi. . Pokoknya berusaha gak marah lah mbak meskipun ya pernah saya agak nada tinggi mbak ngomongnya. Apalagi kan perawat ceweknya lebih banyak daripada cowok. Jadi yang cowok harus ngalah. inshAllah sabar terus (Perawat R)”.

"Pasien cewek selama ini memang ada yang gak mau sama perawat laki-laki mbak. mungkin sungkan ya mbak sama kita tapi kalo pasien cewek terus ibu-ibu wah.. alamat biasanya suka ngomel kalo sudah gak mau sama perawat laki-laki. Repot kadang mbak soalnya kan visite juga gantian mbak untuk ngisi CPPT iya catatan terintegrasi pasien itu ya mulai lah lagi ngebujuk gitu mbak (Perawat R)”.

\section{PEMBAHASAN}

Pernyataan yang diungkapkan perawat, memberikan pelayanan keperawatan di ruang inap dengan acuan waktu pemberian obat, penggantian cairan infus yang telah habis atau diganti dan mengingatkan pasien untuk seka. Pada saat megingatkan untuk seka banyak pasien yang tidak mau dilayani oleh perawat dan selalu tidak menuruti jadwal seka. Perawat ruang rawat inap tidak selalu memberikan pelayanan seka terhadap pasien dan biasanya selalu mengandalkan pihak keluarga yang ada atau berkunjung untuk menyekakan pasien. Perawat yang bertugas di ruang rawat inap mengalami berbagai emosi ketika menghadapi pasien. Perawat di ruang rawat inap merasa kurang dihargai.

Peran perawat yang utama adalah sebagai pemberi layanan keperawatan. Layanan keperawatan tersebut berupa asuhan keperawatan keperawatan secara langsung kepada 
pasien (individu, keluarga, maupun komunitas) sesuai dengan kewenangannya. Layanan keperawatan tersebut merupakan bentuk bantuan yang diberikan kepada pasien yang mengalami kelemahan fisik dan mental, keterbatasan pengetahuan, serta kurangnya kemauan dalam melaksanakan hidup sehat secara mandiri (Desimawati, 2013). Menurut Ariani \& Kristiana (2017), Perawat menjalankan berbagai peran dan bekerja di departemen yang berbeda. Pada ruang rawat inap membutuhkan perawat yang mempunyai pengetahuan dan keterampilan khusus dalam menjalankan proses merawat pasien, perawat dituntut untuk selalu menggunakan metode berpikir kirtis, melakukan koordinasi pelayanan kesehatan, melaksanakan berbagai terapi terkait dengan kondisi pasien dan harus selalu siap untuk memberi pengetahuan kesehatan kepada pasien. Ariani \& Kristiana (2017), Perawat ruang rawat inap intensitas bertemu dengan pasien lebih sering dilakukan, karena pasien membutuhkan pemantauan dan pengawasan berkala, sehingga perawat merupakan salah satu profesi pelayanan kesehatan yang harus tersedia dalam 24 jam penuh. Tugas pokok (job description) seorang perawat dalam mengkoordinasi perawatan yang dibutuhkan pasien sangat kompleks.

Peraturan Menteri Kesehatan Republik Indonesia Nomor 73 Tahun 2013 mengesahkan bahwa tugas pokok perawat rawat inap antara lain melaksanakan lanjutan keperawatan terhadap individu, melaksanakan analisis kompleks untuk merumuskan diagnosa keperawatan individu, menerima konsultasi evaluasi keperawatan sederhana pada kelompok atau masyarakat, melaksanakan tugas jaga, tugas siaga, tugas khusus, dan tugas kunjungan, menyusun laporan yang meliputi kegiatan dan pelaksanaan tugas. Perawat perlu mengevaluasi emosinya sendiri karena sangat sulit untuk menghindari emosi, sementara pasien sangat peka terhadap emosi yang terpindahkan dari komunikasi interpersonal.

Perawat wanita lebih banyak ada di ruang rawat inap sebanyak 10 perawat perempuan dan 2 perawat laki-laki. Secara khusus perawat membutuhkan kecerdasan emosi yang tinggi. Hal ini dikarenakan perawat merupakan tenaga profesional yang terbanyak dan sering berkomunikasi dengan pasien. Pemberian pelayanan jasa terhadap pasien seharusnya menyenangkan karena pelayanan perawat sangat menentukan baik buruknya citra suatu rumah sakit. Fenomena tersebut pentingnya strategi dalam regulasi emosi perawat ruang rawat inap dengan model regulasi emosi koping yaitu ketika seseorang mengalami tekanan maka dia akan mencari sumber permasalahan kemudian mencoba menelaahnya untuk menemukan inti permasalahan yang sebenarnya. Proses koping diawali dengan problem-focused coping, dilanjutkan dengan appraisal-focused 
coping dan diakhiri dengan emotion-focused coping. Ketika seseorang mengalami masalah, maka dia akan berusaha memecahkan masalah tersebut, menilai dan mengevaluasi masalah untuk memilih strategi yang paling sesuai, jika sudah memilih strategi maka yang dilakukan adalah berpasrah dan berusaha menerima keadaan. Model teoritis dari kalat ini sering disebut dengan model proses dalam regulasi emosi.

Perawat yang memiliki regulasi emosi yang tinggi menjadikan perawat tersebut memiliki kemampuan dalam mengekspresikan dan mengelola emosi serta perasaannya dengan tepat, sehingga seorang individu dapat menunjukkan sikap dan perilaku yang baik sesuai dengan situasi dan kondisi tertentu. Perawat yang memiliki regulasi emosi yang tinggi dengan perilaku prososial yang tinggi dapat diartikan bahwa perawat tersebut memiliki kemampuan dalam mengontrol dan mengekspresikan emosinya dengan tepat sehingga memunculkan perilaku yang positif dan tidak merugikan pihak lain. Perilaku tersebut dapat dilihat dari bagaimana metode perawat dalam mengurangi konflik yang sering terjadi antar rekan kerja, dalam hal ini perawat juga melaksanakan tugasnya dengan baik serta mampu dalam menyelesaikan setiap permasalahan yang terjadi antar individu atau kelompok (Madol, 2016).

Seseorang dengan regulasi emosi yang tinggi mampu berperilaku dengan benar dan menguntungkan dirinya sendiri serta orang lain seperti mampu dalam memberikan pertolongan kepada orang lain, bekerjasama, bersahabat, berbagi, dan sebagainya (Yusuf \& Kristiana, 2017). Maka sebaliknya, jika perawat yang kurang memahami masalah yang sedang dihadapi dan kurang memahami emosi yang dirasakan mengalami kesulitan dalam melakukan modifikasi situasi maupun menafsirkan ulang masalahnya. Dengan kata lain ketika perawat tidak mampu mengenal emosi yang ada dalam dirinya, maka dia tidak mampu mengenal emosi yang harus dia miliki, sesuai dengan keadaan sehingga pekerjaan yang erat dengan perilaku menolong orang lain (pasien) pun sangat rendah. Selanjutnya Anderson mengungkapkan bahwa individu perlu memahami pokok masalah yang sedang dihadapi dan menyatakan dengan jelas situasi sekarang dan situasi yang diinginkan. Tindakan ini membantu individu untuk dapat fokus pada hal positif yang dilakukan.

\section{SIMPULAN}

Berdasarkan hasil penelitian dan pembahasan diuraikan sebelumnya, dapat disimpulkan bahwa pentingnya regulasi emosi pada perawat ruang rawat inap Klinik Utama Rawat Inap Usada Buana. Model regulasi emosi yang tepat untuk perawat ruang rawat inap adalah model proses koping. Proses koping diawali dengan problem-focused 
coping, dilanjutkan dengan appraisal-focused coping dan diakhiri dengan emotionfocused coping. Ketika seseorang mengalami masalah, dia berusaha memecahkan masalah tersebut, menilai dan mengevaluasi masalah untuk memilih strategi yang paling sesuai. Perawat yang memiliki regulasi emosi yang tinggi menjadikan perawat tersebut memiliki kemampuan dalam mengekspresikan dan mengelola emosi serta perasaannya dengan tepat, sehingga seorang individu dapat menunjukkan sikap dan perilaku yang baik sesuai dengan situasi dan kondisi tertentu. Maka sebaliknya, ketika perawat tidak mampu mengenal emosi yang ada dalam dirinya, maka dia tidak mampu mengenal emosi yang harus dia miliki, sesuai dengan keadaan sehingga pekerjaan yang erat dengan perilaku menolong orang lain (pasien) pun sangat rendah.

\section{UCAPAN TERIMA KASIH}

Penulis mengucapkan banyak terima kasih kepada Prof. Dr. Suryanto, M. Si Guru Besar Fakultas Psikologi Universitas Airlangga, Dr. Windijarto, SE., MBA selaku Ketua Program Studi S2 PSDM Universitas Airlangga, Manajer Klinik Utama Rawat Inap Usada Buana Surabaya, para responden serta semua pihak yang telah banyak membantu menyelesaikan penyusunan penelitian ini.

\section{DAFTAR PUSTAKA}

Anggraini, F. W. \& Prasetyo, A. R., 2015. Hardiness dan Subjective Well-Being pada Perawat. Jurnal Empati, IV(4), p. 74.

Ariani, M. \& Kristiana, I. F., 2017. Hubungan Antara Regulasi Emosi dengan Organizational Citizenship Behavior pada Perawat RSUD HJ. Anna Lasmanah Banjarnegara. Jurnal Empati, VI(1), pp. 270-275.

Desimawati, D. W., 2013. Hubungan Layanan Keperawatan Dengan Tingkat Kepuasan Pasien Rawat Inap di Puskesmas Sumbersari Kabupaten Jember. Skripsi ed. Jember: Universitas Jember.

Madol, J., 2016. Hubungan Antara Kecerdasan Emosi dengan Kecenderungan Depresi pada Perawat Laki-Laki di Rumah Sakit. Skripsi ed. Salatiga: Fakultas Psikologi Universitas Kristen Satya Wacana.

Mayangsari, E. D. \& Ranakusuma, O. I., 2014. Hubungan Regulasi Emosi dan Kecemasan pada Petugas Penyidik Polri dan Penyidik PNS. Jurnal Psikogenesis, III(1), p. 18.

Meilani, V., 2018. Hubungan Antara Regulasi Emosi dengan Perilaku Prososial pada Perawat RSUD DR. Moewardi. Skripsi ed. Surakarta: Fakultas Psikologi Universitas Muhammadiyah Surakarta.

Pratisti, W. D. \& Prihartanti, N., 2012. Konsep Mawas Diri Suryomentaram dengan Regulasi Emosi. Jurnal Penelitian Humaniora, XIII(1), p. 21.

Putri, D. W. L., n.d. Hubungan antara Regulasi Emosi dengan Perilaku Prososial pada Perawat Rumah Sakit Jiwa Grahasia Yogyakarta.

Ratnasari, S. \& Suleeman, J., 2017. Perbedaan Regulasi Emosi Perempuan dan Laki-Laki di Perguruan Tinggi. Jurnal Psikologi Sosial , XV(1), p. 35. 
Ade Ayu Mitra Ramadita Daluas, Suryanto, Sendy Ayu Mitra Uktutias : Nursing Emotional Regulation ....

Rif'ati, M. I. \& Suryanto, 2018. Pola Regulasi Emosi Orang Tua dengan Anak Temper Tantrum, Surabaya: Temu Ilmiah Nnasional Ikatan Psikologi Sosial 2018 Conference Call for Paper (2-3) Universitas Katolik Widya Mandala Surabaya.

Silaen, A. C. \& Dewi, K. S., 2015. Hubungan Antara Regulasi Emosi dengan Asertivitas (Studi Korelasi pada Siswa di SMA Negeri 9 Semarang). Jurnal Empati, IV(2), p. 176.

Smith, M. A. \& Argiati, S. H. B., 2013. Kepribadian Tangguh (Hardiness) pada Perempuan Penderita Pasca Stroke. Jurnal Spirits, III(2), p. 3.

Yunis \& Rahardjo, P., 2011. Hubungan antara Regulasi Emosi dengan Sikap Anggota Polisi Sektor Polres Purbalingga terhadap Efektivitas Kerja. Psycho Idea, IX(2), p. 33.

Yusuf \& Kristiana, 2017. Hubungan Antara Regulasi Emosi dengan Perilaku Prososial pada Siswa Sekolah Menengah Atas. Jurnal Empati, pp. 98 - 104. 